\title{
PENGARUH SELF EFFICACY TERHADAP KINERJA KARYAWAN DENGAN KEPUASAN KERJA SEBAGAI VARIABEL INTERVENING (STUDI PT. ULTRAJAYA MILK INDUSTRY, TBK SURABAYA BAGIAN MARKETING)
}

\author{
Fauzan Ali \\ Universitas Negeri Surabaya \\ fauzanali@mhs.unesa.ac.id \\ Dewie Tri Wijayati Wardoyo \\ Universitas Negeri Surabaya \\ dewiewijayati@unesa.ac.id
}

\begin{abstract}
The purpose of this research is to test and analyze the role of Job satisfaction as an intervening variable between self-efficacy and employee performance. Research object at PT. Ultrajaya Milk Industry, Tbk Surabaya area, is the marketing department. Several factors that can improve employee performance are the employees' sense of security and comfort in the work environment. This research is using a quantitative approach. The population in this study are 56 employees at PT. Ultrajaya Milk Industry, Tbk in Surabaya Area. The data analysis technique used Structural Equation Model Partial Least Square with software SmartPLS version 3.0. The technique of collecting data using questionnaires and interviews. The result showed that self-efficacy has no significant effect on employee performance. Self-efficacy has a positive and significant effect on job satisfaction. Job satisfaction has a positive and significant effect on employee performance. Job satisfaction as an intervening variable affects the relationship between self-efficacy and employee performance at PT. Ultrajaya Milk Industry, Tbk in Surabaya Area, is the marketing department. This study implies that if the company wants to improve employee performance, then employee job satisfaction must be realized, maintain a comfortable work environment, and provide motivation to training to maximize and increase self-efficacy.
\end{abstract}

Keywords: Employee performance; Job satisfaction;Self-efficacy.

\section{PENDAHULUAN}

Semakin ketat persaingan dalam dunia bisnis menghadapkan suatu organisasi/perusahaan dalam memenuhi kebutuhan publik yang memiliki daya saing yang efisien dan ketat. Dalam meningkatkan efisiensi tersebut tentu memerlukan pula sumber daya manusia berkualitas (Ace, 2017). Pada sumber daya manusia akan senantiasa melekat pada setiap organisasi sebagai salah satu faktor penentu akan peranan dan keberadaannya untuk memberikan kontribusi yang selaras dengan tujuan yang ingin perusahaan capai secara efektif dan efisien. Di antara aspek-aspek yang mendukung, yang menjadi aspek yang cukup diperhatikan terkait dengan keadaan perekonomian adalah karyawan, hal tersebut menandakan bahwa sumber daya manusia masih menjadi hal yang sangat diperhatikan oleh industri untuk bertahan dalam persaingan industri yang sangat kompetitif. Karyawan sebagai aspek yang penting mempunyai tenaga untuk mengendalikan dan menetapkan keberlangsungan sebuah industri. Kepuasan kerja ialah faktor penting untuk tetap menjaga kestabilan karyawan terkait keberlangsungan industri (Narendra, 2017).

Kehadiran karyawan dalam perusahaan merupakan sesuatu yang harus diperhatikan oleh industri untuk tercapainya target dari perusahaan. Industri wajib mengelola aset dari sumber daya manusia yang dimilikinya secara optimal. Karena pentingnya peranan dari sumber daya manusia, maka perusahaan diupayakan untuk harus memiliki karyawan yang unggul dan bermutu yang bisa memberikan kontribusi penuh untuk kesuksesan perusahaan. Karena karyawan adalah faktor utama dalam suatu perusahaan, untuk bisa sukses atau tidaknya perusahaan tergantung oleh karyawan yang dimiliki. Maka diperlukan pengelolaan tenaga kerja secara optimal dan dilakukan dengan baik dan benar (Agustyna dan Prasetio, 2020). Karyawan ialah aspek terpenting terkait menentukan keunggulan dan kemajuan suatu industri. Bahwa karyawan ialah faktor terpenting selain faktor yang lain, seperti bahan baku dan alat kerja (Arda, 2017). Wijayati et al (2020) menjelaskan terdapat 
Fauzan Ali, Dewie Tri Wijayati Wardoyo. Pengaruh Self efficacy terhadap Kinerja Karyawan dengan Kepuasan Kerja sebagai Variabel Intervening (Studi PT. Ultrajaya Milk Industry, Tbk Surabaya Bagian Marketing)

empat aspek dalam pembinaan kinerja adalah mentoring, konfrontasi, pelatihan, dan pembinaan karier.

Menurut Ary dan Sriathi (2019), self efficacy memengaruhi kinerja karyawan secara signifikan positif. Harjono et al (2015) menjelaskan self efficacy secara langsung berpengaruh terhadap kinerja. Namun Prasetya (2013) dan Noviawati (2016) menjelaskan bahwa self efficacy tidak berpengaruh terhadap kinerja individu. Menurut Tojjari et al (2013), self efficacy memiliki pengaruh positif terhadap kepuasan. Menurut Dewi dan Dewi (2015), secara simultan self efficacy memiliki pengaruh positif kepada job satisfaction. Narendra (2017) mengungkapkan bahwa self efficacy memberikan dampak signifikan positif kepada job satisfaction. Namun menurut Kilapong (2013), Self efficacy tidak memberikan dampak kepada kepuasan kerja. Faktor kepuasan kerja berkaitan terhadap kinerja yang ditunjukkan karyawan, semakin puas dengan pekerjaan karyawan akan meningkatkan kinerjanya. Pada beberapa penelitian sebelumnya, job satisfaction memberikan pengaruh positif kepada employee performance.

Fenomena mengenai self efficacy pada PT. Ultrajaya Milk Industry, Tbk diketahui masih ada beberapa karyawan yang merasa bahwa mereka kurang peduli terhadap pemenuhan target mereka, karena mereka beranggapan jika dapat mencapai target bulan ini maka perusahaan akan menaikkan target mereka di bulan berikutnya, padahal jika salesman bisa mencapai target maka mereka akan mendapat insentif pada tanggal 10 setiap bulannya.

Berdasarkan permasalahan yang terjadi di PT. Ultrajaya Milk Industry, Tbk Surabaya tersebut, penelitian ini bertujuan untuk mengukur dan mengkaji pengaruh self efficacy terhadap kinerja karyawan di PT. Ultrajaya Milk Industry, Tbk area Surabaya bagian marketing, untuk mengukur dan mengkaji pengaruh kepuasan kerja terhadap kinerja karyawan pada PT. Ultrajaya Milk Industry, Tbk area Surabaya bagian marketing, untuk mengukur dan mengkaji pengaruh Self efficacy terhadap kepuasan kerja di PT. Ultrajaya Milk Industry, Tbk area Surabaya bagian marketing dan untuk mengukur dan mengkaji pengaruh self efficacy terhadap kinerja karyawan dengan kepuasan kerja sebagai mediasi di PT. Ultrajaya Milk Industry, Tbk area Surabaya bagian marketing.

\section{KAJIAN PUSTAKA DAN PENGEMBANGAN HIPOTESIS}

\section{Self efficacy}

Self efficacy ialah suatu keyakinan individual terhadap kemampuan mereka dalam mejalankan dan mengatur tugas yang diberikan untuk mencapai suatu tujuan (Priyantono, 2017). Self efficacy lebih mengarah pada penilaian individu akan kemampuannya. Pentingnya self efficacy akan berpengaruh pada usaha yang diperlukan dan pada akhirnya terlihat dari kinerja karyawannya Noviawati (2016). Self efficacy merupakan keyakinan seseorang mengenai kemungkinannya untuk sukses dalam mencapai tujuan yang ditentukan (Kilapong, 2013). Ardanti dan Rahardja (2017) menyatakan bahwa karyawan yang mempunyai rasa self efficacy yang baik ialah karyawan yang mampu memenuhi target yang diberikan, sehingga dapat memengaruhi kinerja mereka. Sebaliknya, jika karyawan mempunyai self efiicacy yang buruk maka individu tersebut merasa bahwa target yang diberikan adalah beban, sehingga mereka tidak bisa mencapai tingkatan kinerja yang diinginkan. Menurut Cherian dan Jacob (2013), self efficacy merupakan pengendalian diri saat mengalami masalah dan mencari solusi terkait masalah yang efektif dan efisien.

Self efficacy memiliki beberapa indikator dari beberapa penelitian di antaranya menurut Priyantono (2017) tolok ukur yang digunakan untuk mengukur self efficacy menggunakan empat indikator yakni: rasa mampu melakukan pekerjaan, kemampuan yang lebih baik, senang pekerjaan yang menantang, dan kepuasaan terhadap pekerjaan. Menurut Ardanti dan Rahardja (2017), ada enam indikator penilaian yakni, karyawan merasa pekerjaan yang dilakukan sesuai dengan kemampuan diri, karyawan mampu beradaptasi dengan pekerjaan di dalam perusahaan, karyawan merasa pekerjaan yang dikerjakan memenuhi ekspektasi, karyawan mempunyai pengetahuan secara teknis dalam menyelesaikan pekerjaan, karyawan merasa mempunyai kemampuan yang sama/lebih dari rekan 
kerjanya dan merasa pengalaman dalam pekerjaan sebelumnya membantu karyawan dalam memperoleh rasa percaya diri dalam pekerjaan. Dari beberapa indikator di atas, penelitian ini memilih indikator yang paling mendekati dengan fenomena-fenomena yang terjadi di lapangan, yakni menurut Ardanti dan Rahardja (2017), yang memiliki enam indikator penilaian.

\section{Kepuasan Kerja}

Menurut Prasetya (2013), perilaku seseorang dalam menghadapi tugas yang diberikan, seseorang dengan rasa kepuasan kerjanya yang baik mempunyai perilaku yang positif terhadap tugas yang diberikan, di lain sisi individu yang memiliki kepuasan yang rendah terhadap tugas yang diberikan cenderung mempunyai perilaku yang negatif terhadap tugas yang diberikan, hal tersebut disebut kepuasan kerja. Menurut Robbins dan Judge (2016), kepuasan kerja ialah rasa yang memberikan energi positif kepada suatu pekerjaan yang disebabkan dari hasil evaluasi kerja, kepuasan kerja menjadi perwakilan dari sikap yang diberikan karyawan terhadap perusahaan. Kepuasan kerja ialah di mana karyawan merasa puas dan rasa sesuai yang mereka harapkan terhadap pekerjaan yang diberikan, kepuasan kerja menjadi hal yang berdampak kepada kinerja karyawan. Karyawan yang mempunyai rasa job satisfaction yang baik hingga hal tersebut akan memengaruhi hasil kinerjanya (Anam, 2017). Kepuasan kerja dapat memengaruhi kinerja yang dimiliki oleh karyawan, karena saat karyawan merasa kepuasan kerja hal itu berpengaruh pada kinerja yang diberikan oleh karyawan itu sendiri menjadi lebih efektif. Sehingga, perusahaan juga wajib mengamati aspek-aspek yang dapat berdampak pada kepuasan kerja, contohnya gaji, kondisi lingkungan kerja, promosi, hubungan kerja, keadilan, dan pemenuhan kebutuhan. Kepuasan kerja yang dimiliki oleh masing-masing karyawan bisa mengoptimalkan kinerja yang mereka miliki (Agustyna dan Prasetio, 2020)

Menurut Yasa dan Suandra (2017), tolok ukur yang digunakan dalam mengukur variabel kepuasan kerja, terdiri dari lima indikator, yakni: Upah, Promosi, Rekan kerja, Atasan dan Pekerjaan intu sendiri. Sedangkan Robbins dan Judge (2016) mengemukakan enam indikator penilaian terhadap kepuasan kerja yakni, rekan kerja, pekerjaan secara umum, pekerjaan itu sendiri, gaji, kesempatan promosi, dan pengawasan. Menurut Changgriawan (2017) antara lain: kepuasan karyawan terhadap gaji/upah, kepuasan karyawan akan pekerjaan itu sendiri, kepuasan terhadap rekan kerja, puas akan kesempatan promosi yang diterima karyawan, kepuasan karyawan dari perlakuan pengawas (atasan). Pada penelitian ini memilih indikator yang dikemukakan oleh Robbins dan Judge (2016), karena kesesuaian dengan fenomena di lapangan yakni, rekan kerja, pekerjaan secara umum, pekerjaan itu sendiri, gaji, kesempatan promosi, dan pengawasan.

\section{Kinerja Karyawan}

Kinerja seorang karyawan memiliki peran penting terhadap keberhasilan suatu perusahaan atau organisasi. Menurut Arda (2017), kinerja adalah sebuah pencapaian hasil kerja yang dilakukan oleh karyawan selama periode tertentu dan dibandingkan dengan standar yang telah ditentukan oleh perusahaan. Kinerja karyawan ialah bagaimana kontribusi karyawan terhadap perusahaan, baik dalam absensi di tempat kerja, kualitas kerja, kuantitas kerja masa kerja dan sikap dalam lingkungan perusahaan (A. N. Candra, 2017). Bagaskara dan Rahardja (2018) menyatakan bahwa kinerja karyawan merupakan aspek yang krusial bagi masa depan perusahaan. Maka dari itu sebuah kewajiban untuk perusahaan guna menciptakan karyawan yang sanggup menciptakan kinerja yang optimal untuk tercapai tujuan perusahaan. Menurut Priyantono (2017), kinerja karyawan merupakan hasil kerja yang dicapai oleh sumber daya manusia dalam periode waktu yang ditentukan.

Mathis dan Jackson (2011) mengatakan bahwa terdapat lima indikator yang menjadi ukuran kinerja karyawan, kuantitas dari hasil, kualitas dari hasil, ketepatan waktu dari hasil, kehadiran dan kemampuan bekerjasama. Berdasarkan Mangkunegara (2009), indikator kinerja adalah kualitas, kuantitas, pelaksanaan tugas dan tanggung jawab. Menurut Rahman dan Kistyanto (2019)menjelaskan indikator kinerja karyawan adalah, kuantitas dari hasil, kualitas dari hasil, ketepatan waktu dari hasil, dan kehadiran di tempat kerja. Penelitian ini menggunakan indikator dari Mathis dan Jackson (2011), karena kesesuaian dengan fenomena di lapangan, adapun indikator tersebut yakni kuantitas, kualitas, ketepatan waktu, kehadiran dan kemampuan bekerja sama dalam tim 
Fauzan Ali, Dewie Tri Wijayati Wardoyo. Pengaruh Self efficacy terhadap Kinerja Karyawan dengan Kepuasan Kerja sebagai Variabel Intervening (Studi PT. Ultrajaya Milk Industry, Tbk Surabaya Bagian Marketing)

\section{Hubungan antar Variabel}

Menurut Ardanti dan Rahardja (2017) Self efficacy berdampak positif kepada kinerja karyawan. Ary dan Sriathi (2019) Self-efficacy berpengaruh signifikan positif terhadap kinerja karyawan. Menurut Desiana (2018) Self efficacy berpengaruh kepada kinerja karyawan. Namun menurut Sihombing et al. (2018) Self efficacy tidak memiliki pengaruh yang signifikan di PT. PLN Area Manado Selatan. Menurut Prasetya et al. (2013) mengemukakan adanya dampak antara Self efficacy yang tidak berpengaruh dengan kinerja. Selanjutnya menurut Noviawati (2016), Self efficacy memiliki tidak berpengaruh kepada kinerja karyawan. Dari pendapat para pendahulu menyatakan bahwa, self efficac berdampak signifikan terhadap kinerja karyawan. Karena, self efficacy merupakan keyakinan masingmasing indivudu dalam mengerjakan tugas yang diberikan.

H1: Diduga self efficacy berpengaruh terhadap kinerja karyawan pada PT. Ultrajaya Milk Industry, Tbk Bagian Marketing.

Pada riset yang dipaparkan Santoso dan Dewi (2019) menunjukkan adanya pengaruh positif antara self efficacy pada job satisfaction. Penelitian tersebut menyatakan rasa efikasi yang dimiliki karyawan memberi dampak terhadap job satisfaction. Menurut Santoso dan Dewi (2019) self efficacy memengaruhi kepuasan kerja secara positif serta signifikan. Y. Candra (2019) menyatakan self efficacy memengaruhi kepuasan kerja secara signifikan positif. Ardiani dan Mulyana (2018) menyatakan adanya pengaruh signifikan antara Self efficacy dan kepuasan. Salanka dan Dotulong (2015) self efficacy, harga diri, dan lingkungan kerja secara langsung dapat memengaruhi kepuasan kerja. Dari penelitian terdahulu menyatakan bahwa, rasa self efficacy dapat memengaruhi kepuasan kerja. Karena keyakinan individu karyawan bisa meningkatkan dengan baiknya lingkungan kerja dan ekspektasi mereka terhadap pekerjaa.

H2: Diduga self efficacy berpengaruh terhadap kepuasan kerja pada PT. Ultrajaya Milk Industry, Tbk Bagian Marketing.

Arda (2017) menyatakan kepuasan kerja memengaruhi kinerja secara signifikan. Menurut Kartika et al (2018), terdapat pengaruh positif antara job satisfaction dan employee performance. Anam (2017) membuktikan jika kepuasan kerja memengaruhi secara positif terhadap kinerja karyawan. Dari beberapa studi di atas, bisa diterangkan jika kepuasan kerja memengaruhi kinerja karyawan secara positif. Sunanda (2019) menyatakan bahwa kepuasan kerja berpengaruh positif dan signifikan terhadap kinerja karyawan. Sedangkan Nurul (2019) menunjukkan bahwa kepuasan kerja tidak berpengaruh kepada kinerja karyawan. Dari pendapat para ahli di atas, kepuasan kerja dapat membuat kinerja karyawan meningkat. Karena karyawan jika merasakan kepuasan dalam bekerja mereka akan mencari cara bagaimana bisa membuat hasil pekerjaannya maksimal.

H3: Diduga kepuasan kerja berpengaruh terhadap kinerja karyawan pada PT. Ultrajaya Milk Industry, Tbk Bagian Marketing.

Pada dasarnya karyawan yang memiliki self efficacy tinggi akan memiliki kepuasan kerja yang tinggi, dan kepuasan kerja karyawan tinggi akan meningkatkan kinerja karyawan (Kartika et al, 2018). Santoso and Dewi (2019) menyatakan adanya pengaruh antara self efficacy dan kepuasan kerja. Sedangkan Priyantono (2017), mengemukakan bahwa adanya pengaruh positif antara kinerja dan kepuasan kerja. Maka kepuasan kerja memiliki indikasi memediasi self efficacy dan kinerja karyawan. Menurut Mukrodi (2018), self efficacy memberikan dampak yang signifikan positif kepada employee performance. Agustyna dan Prasetio (2020) Persepsi dukungan organisasi dan kepuasan kerja berpengaruh signifikan positif terhadap kinerja karyawan pada PT Great Citra Lestari. Menurut Kartika et al (2018), self efficacy memengaruhi kepuasan kerja secara signifikan positif self efficacy memengaruhi kinerja secara signifikan positif.

H4: Diduga kepuasan kerja memediasi self efficacy terhadap kinerja karyawan pada PT. Ultrajaya Milk Industry, Tbk Bagian Marketing. 


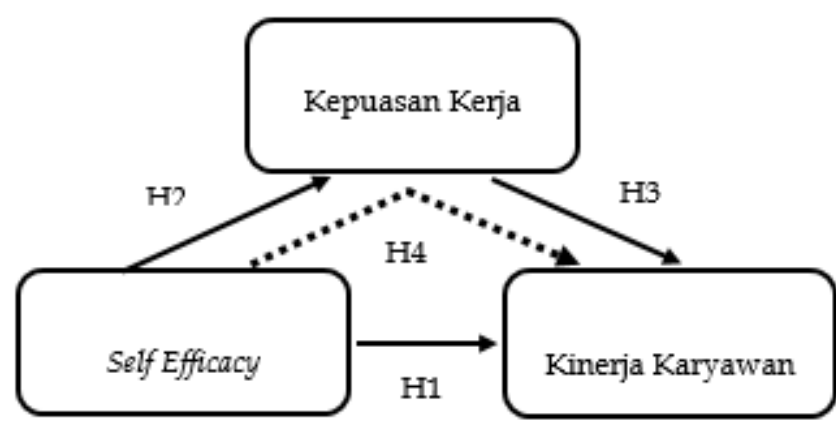

Sumber : data diolah penulis

Gambar 1. KERANGKA KONSEPTUAL

\section{METODE PENELITIAN}

Penelitian tersebut menggunakan metode kualitatif. Penelitian kuantitatif adalah penelitian yang dibangun melalui pengembangan hipotesis yang diuji secara kuantitatif hingga menghasilkan hipotesa yang baru. Data atau informasi tersebut yang nantinya akan digunakan untuk membahas rumusan masalah yang diajukan. Penyebaran kuesioner, wawancara dan observasi penelitian pada PT. Ultrajaya Milk Industry, Tbk Surabaya, yang berlokasi di Berbek Industry VII No. 21 - Kecamatan Waru, Kabupaten Sidoarjo. Populasi yang digunakan adalah karyawan pada divisi Marketing di PT. Ultrajaya Milk Industry, Tbk area Surabaya yang berjumlah 56 orang. Pada penelitian ini menggunakan jenis sampel jenuh dalam pengambilan sampel-nya, di mana semua bagian populasi anggota populasi digunakan menjadi sampelnya. Pada penelitian ini ukuran sampel diambil dari seluruh populasi karyawan di divisi Marketing yaitu 56 karyawan.

\section{HASIL DAN PEMBAHASAN}

Berikut gambaran ini adalah karakteristik responden yang didasarkan pada usia, jenis kelamin, pendidikan terakhir status pernikahan dan masa kerja. Penelitian ini juga mengukur rata-rata nilai yang diberikan oleh responden bersumber dari variabel yang digunakan seperti, Self efficacy, job satisfaction dan employee performance. Adapun penjelasan sebagai berikut, rata-rata indikator variabel Self efficacy yaitu karyawan merasa pekerjaan yang dilakukan cocok dengan kemampuan diri sebesar 3,64, karyawan mampu menyesuaikan diri dengan pekerjaan di dalam perusahaan sebesar 3,55, karyawan merasa pekerjaan yang dilakukan memenuhi ekspektasi diri sebesar 3,61, karyawan memiliki pengetahuan teknis untuk menuntaskan pekerjaan senilai 3,64, karyawan merasa mempunyai keahlian yang sama ataupun lebih dari rekan kerja sebesar 3, 57 serta merasa pengalaman tadinya menolong karyawan dalam mendapatkan rasa yakin dalam buat mengerjakan tugasnya 3,64. Adapun rata-rata indikator kepuasan kerja yakni, rekan kerja sebesar 3,643, pekerjaan secara umum sebesar 3,680, pekerjaan itu sendiri 3,625, gaji sebesar 3,673, kesempatan promosi senilai 4,085 dan supervisi (pengawasan) sebesar 3,660. Selanjutnya rata-rata indikator kinerja karyawan adalah sebagai berikut, ketepatan waktu sebesar 4,055, kuantitas kerja sebesar 4,080, kualitas pekerjaan sebesar 3,750, kehadiran sebesar 3,945 dan kemampuan bekerja sama sebesar 3,995.

\section{Convergent Validity}

Masing-masing variabel memiliki nilai convergent validity yang baik yakni $>0,50$ sehingga dapat dikatakan semua variabel valid, hasil detail sesuai seperti gambar 2: 
Fauzan Ali, Dewie Tri Wijayati Wardoyo. Pengaruh Self efficacy terhadap Kinerja Karyawan dengan Kepuasan Kerja sebagai Variabel Intervening (Studi PT. Ultrajaya Milk Industry, Tbk Surabaya Bagian Marketing)

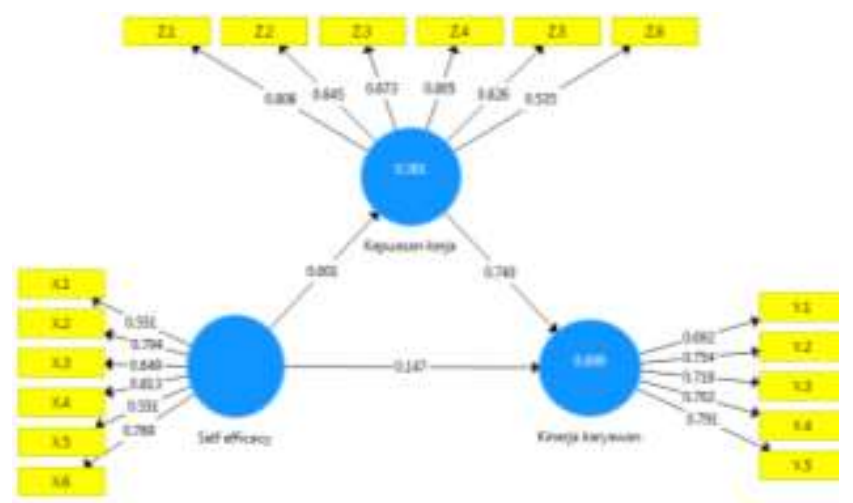

Sumber: Output SmartPLS

Gambar 2. MEASUREMENT MODEL

Composite Reability dan Cronbach's Alpha

Tabel 1.

COMPOSITE RELIABILITY DAN CRONBACH'S ALPHA

\begin{tabular}{lcc}
\hline \multicolumn{1}{c}{ Variabel } & Composite Reability & Cronbach's Alpha \\
\hline Self efficacy & 0,842 & 0,777 \\
Kinerja Karyawan & 0,852 & 0,786 \\
Kepuasan Kerja & 0,847 & 0,779 \\
\hline
\end{tabular}

Sumber: Ali (2020)

Dari tabel 1 dapat dilihat bahwa semua variabel memiliki nilai composite reliability lebih besar dari 0,60. Dengan rincian self efficacy sebesar 0,842, kinerja karyawan 0,852 dan kepuasan kerja sebesar 0,847 . Dengan demikian semua variabel telah memenuhi kriteria nilai composite reliability, sehingga dapat dikatakan bahwa data tersebut sudah reliabel. Nilai tertinggi composite reliability berada pada variabel kepuasan kerja yakni sebesar 0,852, Jadi, indikator dari variabel kepuasan kerja memiliki realibilitas lebih tinggi dibanding variabel lainnya.

Nilai cronbach's alpha lebih besar dari 0,70. Dengan rincian self efficacy sebesar 0,777, kinerja karyawan sebesar 0,786 dan kepuasan kerja 0,775. Dengan demikian semua variabel telah memenuhi kriteria nilai cronbach's alpha, sehingga dapat dikatakan bahwa data tersebut sudah reliabel. Sama halnya dengan composite reliability, nilai tertinggi cronbach's alpha juga berada kinerja karyawan sebesar 0,779 artinya indikator yang digunakan untuk pengukur variabel kinerja karyawan tingkat realibilitasnya lebih tinggi dibandingkan dengan indikator pada variabel lainnya.

\section{R-Square}

Tabel 2.

\section{R-SQUARE MODEL}

\begin{tabular}{lc}
\hline \multicolumn{1}{c}{ Variabel } & R-Square \\
\hline Self efficacy & 0,361 \\
Kinerja Karyawan & 0,699 \\
Kepuasan Kerja &
\end{tabular}

Sumber: Ali (2020)

Berdasarkan tabel 2, R-Square menunjukkan Self efficacy terhadap kepuasan kerja memberikan nilai 0,361 hal ini berarti pengaruh self efficacy terhadap kinerja karyawan kerja tergolong moderat karena di atas 0,33 . Nilai $R$-Square 0,361 menunjukkan bahwa kinerja karyawan mampu dijelaskan oleh self efficacy sebesar $36,1 \%$ dan $63,9 \%$ lainnya diakibatkan oleh faktor lain. Nilai pengaruh self efficacy 
terhadap kepuasan kerja sebesar 0,699 tergolong kuat, karena di atas 0,67. Artinya variabel kepuasan kerja dapat dijelaskan oleh self efficacy sebesar $69,9 \%$ dan $30.1 \%$ dipengaruhi oleh aspek lainnya di luar variabel penelitian. Semakin mendekati angka $1, R$-Square semakin baik.

Tabel 3.

PENGARUH LANGSUNG DAN TIDAK LANGSUNG

\begin{tabular}{lccc}
\hline \multicolumn{1}{c}{ Variabel } & OS & T-Statistic & Keterangan \\
\hline Self efficacy $\rightarrow$ Kinerja Karyawan & 0,147 & 1,323 & H1 Ditolak \\
Self efficacy $\rightarrow$ Kepuasan Kerja & 0,601 & 8,899 & H2 Diterima \\
Kepuasan kerja $\rightarrow$ Kinerja Karyawan & 0,740 & 9,246 & H3 Diterima \\
Self efficacy $\rightarrow$ kepuasan kerja $\rightarrow$ Kinerja Karyawan & 0,444 & 5,707 & H4 Diterima \\
\hline
\end{tabular}

Sumber: Ali (2020)

Pada tabel 3, dampak dari self efficacy pada kinerja karyawan memiliki nilai $t$-statistics 1,323 < 1,96 dengan ini dapat dijelaskan bahwa self efficacy memberikan pengaruh secara tidak signifikan, dan angka koefisien estimate 0,147 dan bertanda positif, yang memiliki makna bahwa semakin baik dari self efficacy maka bisa meningkatkan kinerja karyawan, namun tidak secara signifikan namun dalam persentase yang rendah. Selanjutnya Self efficacy pada kepuasan kerja memiliki nilai $t$-statistics 8,899 $>1,96$. Dapat dijelaskan bahwa self efficacy memberikan pengaruh yang signifikan dengan angka koefisien estimate 0,601 bertanda positif. Yang bermakna apabila semakin tinggi self efficacy maka kepuasan kerja akan semakin baik pula.

Kepuasan kerja pada kinerja karyawan memiliki nilai t-statistics 9,246 > 1,96 dengan ini dapat dijelaskan bahwa kepuasan kerja dapat berpengaruh dengan segnifikan terhadap kinerja karyawan, dengan nilai koefisien estimate 0,740 yang bertanda positif. Semakin tinggitingkat kepuasan kerja maka semakin baik pula tingkat kinerja karyawan. Pengaruh tidak langsung memiliki nilai koefisien 0,444 , di lain sisi pengaruh secara langsungnya sebesar 0,147 , hal ini menandakan bahwa self efficacy memiliki nilai pengaruh secara langsung terhadap kinerja lebih kecil dibandingkan dengan pengaruh secara tidak langsung terhadap kinerja karyawan melalui kepuasan kerja.

\section{Pengaruh Langsung dan Tidak Langsung}

Tabel 3 penjelasan hipotesis dapat dilihat dari t-statistik dan original sample. H1 terbukti ditolak, sedangkan $\mathrm{H} 2, \mathrm{H} 3$ dan $\mathrm{H} 4$ terbukti diterima dalam riset ini.

\section{Pengaruh Self efficacy terhadap Kinerja Karyawan}

Dari hasil olah data, bisa diketahui jika Self efficacy tidak berpengaruh kepada kinerja karyawan, kondisi tersebut menjelaskan jika H1 tidak diterima. Sehingga semakin tinggi self efficacy yang dimiliki karyawan, maka tidak memengaruhi kinerja karyawan. Dalam penelitian ini, nilai variabel self efficacy akan berpengaruh lebih besar terhadap kinerja karyawan melalui variabel intervening yakni kepuasan kerja.

Penelitian ini mendukung riset dari Prasetya et al. (2013), jika self efficacy tidak memiliki pengaruh secara signifikan kepada kinerja individual dosen Akuntansi di Perguruan Tinggi se-eks Karisidenan Madiun. Hal ini disebabkan karena dosen merasa kulifikasinya rendah daripada persyaratan yang diminta sehingga dosen merasa kurang yakin dalam melaksanakan tugas dan tidak maksimal dalam mengerjakan tugas. Riset ini mendukung studi dari Sihombing et al (2018), bahwa self efficacay tidak berpengaruh secara signifikan terhadap kinerja karyawan. Temuan ini mendukung Noviawati (2016) yang mengemukakan jika Self efficacy tidak berpengaruh kepada kinerja karyawan. Hal ini dikarenakan karyawan menganggap pekerjaan baru yang diberikan belum diimbangi dengan kejelasan tugas sehingga tak jarang banyak karyawan yang mengabaikan tugas baru yang diberikan dan cenderung menunda-nunda. 
Fauzan Ali, Dewie Tri Wijayati Wardoyo. Pengaruh Self efficacy terhadap Kinerja Karyawan dengan Kepuasan Kerja sebagai Variabel Intervening (Studi PT. Ultrajaya Milk Industry, Tbk Surabaya Bagian Marketing)

Riset ini berbanding terbalik dengan hasil penelitian Desiana (2018), Ary dan Sriathi (2019) dan Ardanti dan Rahardja (2017) baahwa self efficacy memiliki pengaruh signifikan positif kepada kinerja karyawan. Berdasarkan hasil pengujian yang dilakukan jika deskriptif responden untuk variabel self efficacy dalam kategori sedang yakni dengan rata- rata sebesar 3,608. Dalam hal ini nilai self efficacy akan memengaruhi kinerja dengan lebih besar jika memalui variabel pemediasi yakni kepuasan kerja.

Berdasarkan hasil jawaban responden melalui pertanyaan-pertanyaan kuesioner yang diberikan terkait variabel self efficacy pada karyawan PT. Ultrajaya Milk Industry, Tbk area Surabaya yang secara keseluruhan menunjukkan hanya dalam kategori sedang yang dibuktikan dengan nilai mean indikator hanya berada pada nilai 2,34-3,67. Hal ini juga dapat dilihat dari hasil statistik deskriptif di mana dengan mayoritas karyawan memliki masa kerja di bawah lima tahun, hal tersebut membuat moyoritas karyawan belum bisa menyesuaikan diri dengan pekerjaan di dalam perusahaan dan karyawan merasa kemampuan yang mereka miliki masih minim membuat mereka terkadang ragu dalam mengerjakan tugas yang diberikan, sebelum ada arahan dari supervisor. Sejalan dengan hasil wawancara dengan Branch Manager PT. Ultrajaya Milk Industry, Tbk area Surabaya, yang menjelaskan bahwa tidak semua karyawan memiliki nilai self-efficacy yang tinggi. Karena ada beberapa karyawan yang merasa tidak yakin dalam menyelesaikan tugas, contohnya masih ada beberapa di antara mereka yang tidak mencapai target, dikarenakan takut target mereka di bulan depan akan dinaikkan juga, sehingga mereka hanya mencari aman saja.

\section{Pengaruh Self Efficacy terhadap Kepuasan Kerja}

Berdasarkan olah data dengan analisis deskriptif, self efficacy memiliki pengaruh signifikan positif kepada kepuasan kerja. Hal ini menandakan semakin tinggi penerapan self efficacy terhadap kepuasan kerja pada bagian marketing PT. Ultrajaya Milk Industry, Tbk maka semakin baik pula kepuasan kerjanya. Riset ini sejalan dengan Narendra (2017), Y. Candra (2019), Santoso dan Dewi (2019), Ardiani dan Mulyana (2018) dan Salanka dan Dotulong (2015) yang menyatakan jika efikasi diri memengaruhi kepuasan kerja. Objek penelitian diambil pada staff di PDAM Surya Sembada Kota Surabaya.

Hal ini dapat dilihat dari indikator karyawan merasa pekerjaan yang dilakukan cocok dengan kemampuan diri meraka, sehingga merasa dalam bekerja tidak terbebani di luar masalah yang berkaitan dengan teknis perusahaan, dan pada indikator rekan kerja pada variabel kepuasan kerja mendapat nilai yang tinggi, hal ini menandakan rekan kerja (lingkungan kerja) dapat membuat karyawan merasa nyaman selama bekerja di perusahaan. Jika dilihat nilai indikator, supervisi (pengawasan) yang baik juga membuat karyawan merasa gap antara karyawan dan supervisor tidak terlalu jauh. Hal ini menjadi sesuatu yang sangat penting karena mayoritas karyawan memiliki masa kerja yang tergolong baru, membuat karyawan tidak malu bertanya kepada atasan terkait teknis dalam pekerjaan yang diberikan. Di sisi lain segala fasilitas yang diberikan oleh perusahaan membuat karyawan merasa bahwa hak-hak mereka sudah terpenuhi, baik dari gaji, insentif, seragam dan juga BPJS Kesehatan dan Ketenagakerjaan. Hal tesebut membuat para karyawan merasa aman dan nyaman. Selain itu semua kendaraan operasional dari perusahaan juga sudah diasuransikan, sehingga karyawan tidak terlalu khawatir jika sewaktu-waktu terjadi kecelakaan kerja.

Apabila dikaitkan dengan hasil wawancara dengan Branch Manager PT. Ultrajaya Milk Industry, Tbk Area Surabaya, sejauh ini tidak ada masalah terkait dengan kepuasan kerja di PT. Ultrajaya Milk Industry, Tbk bagian marketing, karena perusahaan sudah memenuhi semua hak-hak karyawan seperti, pembayaran gaji tepat waktu, memberi fasilitas pakaian, memberikan asuransi bagi setiap karyawan dan uang jalan pada beberapa bidang. Insentif juga diberikan kepada karyawan yang mampu melampaui target dari perusahaan. Jika karyawan bisa melampaui target dari perusahaan, maka insentif akan cari pada pekan kedua setiap bulan. Hal ini didukung dengan hasil deskriptif 
responden untuk variabel kepuasan kerja, masuk dalam kategori tinggi yakni dengan nilai mean variabel kepuasan kerja 3,727.

\section{Pengaruh Kepuasan Kerja terhadap Kinerja Karyawan}

Hasil olah data menunjukkan bahwa kepuasan kerja berpengaruh signifikan positif kepada kinerja karyawan sehingga $\mathrm{H} 3$ diterima. Hal tersebut menandakan jika karyawan merasakan kepuasan kerja, maka kinerja karyawan akan baik.

Riset ini mendukung penelitian Changgriawan (2017), jika kepuasan kerja berpengaruh signifikan positif kepada kinerja karyawan. hasil tersebut sependapat dengan Anam (2017), Sunanda (2019) dan Arda (2017), jika job satisfaction berpengaruh signifikan positif terhadap kinerja karyawan. Berdasarkan dari jawaban responden melalui pernyataan-pernyataan kuesioner yang diberikan, kepuasan kerja pada PT. Ultrajaya Milk Industry, Tbk Area Surabaya mayoritas ditunjukkan dengan tingginya nilai kuantitas kerja. Perihal tersebut dapat diketahui dari nilai mean indikator sebesar 3,727 dengan katagori tinggi pada three box method.

Terkait dengan kepuasan kerja, kesempatan promosi juga sangat penting terhadap jenjang karir karyawan. Hal ini tercermin dari nilai indikator kesempatan promosi yang tinggi yakni 4,085. Pada indikator kuanitas kerja pada variabel kinerja karyawan mendapat nilai statistik desktiptif yang tinggi, hal ini menandakan bahwa kartyawan PT. Ultrajaya Milk Industry, Tbk bagian marketing menyelesaikan pekerjaan mereka sesuai dengan teknis perusahaan, karena pada bagian marketing selain kualiatas kerja yang dicapai kuantitas merupakan patokan yang sangat penting, karena kinerja karyawan diukur dari seberapa banyak liter yang mereka jual dalam periode tertentu. Dari penjualan tersebut akan diketahui karyawan mana yng akan mecapai target yang diberikan oleh perusahaan. Dari target ini akan diketahui apakah karyawan akan mendapatkan insentif di bulan berikutnya. Pada setiap awal pekan supervisor melakukan briefing kepada karyawan, guna menginformasikan karyawan mana saja yang belum mencapi target dan memberikan masukan terkait masalah yang terjadi di lapangan.

Berdasarkan hasil wawancara dengan brach manager terkait dengan kepuasan kerja, pada dasarnya perusahaan selalu memberi tawaran kepada karyawan yang dirasa cukup memiliki pengalaman kerja di atas 5 tahun untuk bisa naik jabatan, dan karyawan pun merasa tawaran tersebut selalu ada. Hal ini menunjukkan dengan kepuasan kerja yang baik maka akan berbanding lurus dengan kinerja karyawan, begitu pula sebaliknya. Meningkatnya kinerja karyawan dikarenakan ada karyawan yang memiliki rasa kepuasan terhadap pekerjaan mereka dan adanya pendekatan dari supervisor membuat karyawan yang mengalami masalah di lapangan bisa berkonsultasi terkait masalah yang dihadapi, di lain sisi adaya motivasi dari supervisor sangat penting guna meningkatkan kinerja karyawan.

\section{Pengaruh Self Efficacy terhadap Kinerja Karyawan melalui Kepuasan Kerja}

Hasil pengujian menunjukkan bahwa kepuasan kerja menjadi intervening antara self efficacy terhadap kinerja karyawan, Jadi H4 diterima. Penelitian ini mendukung penelitian dari Kartika et al (2018), kepuasan kerja sebagai variabel intervening yang positif dan signifikan antara self efficacy dan kinerja karyawan. Menurut Nugraha (2019), self efficacy memiliki pengaruh signifikan terhadap kinerja karyawan, melalui kepuasan kerja sebagai pemediasi antara self efficacy terhadap kinerja karyawan.

Pada dasarnya karyawan PT. Ultrajaya Milk Industry, Tbk area Surabaya bagian marketing memiliki rasa self efficacy sudah baik namun ada beberapa karyawan yang memiliki rasa self efficacy yang kurang karena beberapa dari mereka masih memiliki masa kerja yang tergolong baru yakni di bawah lima tahun. Hal ini membuat mereka harus menyesuaikan diri dengan pekerjaan yang diberikan. Ini tercermin dari nilai indikator karyawan mampu menyesuaikan diri dengan pekerjaan yang diberikan 
Fauzan Ali, Dewie Tri Wijayati Wardoyo. Pengaruh Self efficacy terhadap Kinerja Karyawan dengan Kepuasan Kerja sebagai Variabel Intervening (Studi PT. Ultrajaya Milk Industry, Tbk Surabaya Bagian Marketing)

pada variabel self efficacy cukup rendah yakni 3,55 pada deskriptif responden. Rendahnya rasa self efficacay bisa dilihat dari beberapa karyawan yang dalam mencapai target yang diberikan terlalu santai di awal bulan dan mereka akan keteteran menjelang akhir bulan. Sehingga membuat banyak karyawan yang tidak sanggup melampaui target yang diberikan oleh perusahaan. Beberapa karyawan hanya sanggup mencapi 80-90\% target yang diberikan.

Di lain sisi, dengan adanya pengawasan maka supervisor bisa secara langsung menyinkronkan masalah di lapangan yang hadapi karyawan dengan memberikan solusi penyelesaian masalahnya, sehingga masalah cepat selesai. Meningkatnya rasa self-efficacy dan kepuasan kerja maka kualitas pekerjaan karyawan bisa meningkat dengan sendirinya. Hal ini menandakan seharusnya kualitas pekerjaan bisa lebih maksimal jika self efficacy dan kepuasan kerja ditingkatkan pula. Karena sejauh ini penilaian Key Performance Indicators (KPI) dihitung dari kuantitas kerja atau volume penjualan dan ketepatan waktu pengiriman, yang mana hal tersebut sudah cukup bagus.

\section{KESIMPULAN}

Bersumber pada hasil pengukuran serta pembahasan yang telah dipaparkan, disimpulkan beberapa hal: pertama, self efficacy tidak berpengaruh terhadap kinerja karyawan, hal ini menunjukkan bahwa semakin baik self efficacy tidak meningkatkan kinerja karyawan pada PT. Ultrajaya Milk Industry, Tbk Area Surabaya bagian Marketing. Kedua, self efficacy memengaruhi kepuasan kerja secara signifikan positif. Hal ini menunjukkan jika semakin tinggi rasa self efficacy maka semakin tinggi pula rasa kepusan kerja pada PT. Ultrajaya Milk Industry, Tbk area Surabaya bagian Marketing. Ketiga, kepuasan kerja memengaruhi kinerja karyawan secara signifikan positif. Hal ini menandakan semakin tinggi rasa kepuasan kerja maka semakin tinggi pula kinerja karyawan pada PT. Ultrajaya Milk Industry, Tbk Area Surabaya bagian Marketing. Terakhir, kepuasan kerja sebagai pemediasi memengaruhi hubungan self efficacy kepada kinerja karyawan di PT. Ultrajaya Milk Industry, Tbk Area Surabaya bagian marketing. Hal tersebut disebabkan karena nilai dari pengaruh secara tidak langsung antara self efficacy pada kinerja karyawan dengan kepuasan kerja sebagai pemediasi menunjukkan nilai koefisien yang lebih besar dibanding dengan pengaruh secara simultan self efficacy kepada kinerja karyawan secara langsung.

Berdasarkan hasil penelitian di atas, self efficacy memiliki potensi dalam meningkatkan kinerja. Pimpinan sebaiknya lebih meningkatkan perhatian dengan cara memberikan pelatihan-pelatihan tentang peningkatan rasa percaya diri pada karyawan, sehingga dapat membantu karyawan untuk mengembangkan diri dan meningkatkan kemampuan yang dimiliknya. Pelatihan ini dapat diberikan secara berkesinambungan. Selain itu peran Supervisor juga sangat penting untuk membangun rasa percaya diri karyawan. Upaya yang dilakukan bisa melalui rapat internal tim untuk membahas kendala-kendala di lapangan, serta memberikan tambahan pengetahuan bagi karyawan yang masa kerjanya tergolong baru. Perusahaan dapat melakukan evaluasi secara periodik agar dapat melihat kinerja karyawan. Evaluasi dapat dilakukan antar bagian agar mendapatkan hasil yang nyata. Penelitian ini hanya dilakukan pada karyawan PT. Ultrajaya Milk Industry, Tbk area Surabaya bagian Marketing. Penelitian selanjutnya sebaiknya melihat self efficacy untuk seluruh karyawan serta mengembangkan beberapa variabel lain seperti beban kerja, motivasi, lingkungan kerja, dan penghargaan dalam mengukur tingkat kepuasan dan kinerja karyawan.

\section{DAFTAR PUSTAKA}

Ace, Arna. (2017). "Pengaruh Kualitas Kehidupan Kerja dan Partisipasi terhadap Kepuasan Kerja Perawat RSUD Bangkinang." JOM FISIP 4 (2): 1-7.

Agustyna, Almaid, and Prasetio, Arif Partono (2020). "Pengaruh Persepsi Dukungan Organisasi dan Kepuasan Kerja terhadap Kinerja Karyawan pada PT Great Citra Lestari.” Jurnal Mitra Manajemen (JMM Online) 4 (1): 28-38. 
Anam, Khoirul, and Edy Rahardja. (2017). "Pengaruh Fasilitas Kerja, Lingkungan Kerja Non Fisik dan Kepuasan Kerja terhadap Kinerja Karyawan (Studi Pada Pegawai Dinas Perindustrian dan Perdagangan Provinsi Jawa Tengah).” Diponegoro Journal of Management 6 (4): 1-11.

Arda, Mutia. (2017). "Pengaruh Kepuasan Kerja dan Disiplin Kerja terhadap Kinerja Karyawan pada Bank Rakyat Indonesia Cabang Putri Hijau Medan.” Jurnal Ilmiah Manajemen Dan Bisnis 18 (1): 45-60. https://doi.org/10.30596/jimb.v18i1.1097.

Ardanti, Desti Marina, and Edy Rahardja. (2017). "Pengaruh Pelatihan, Efikasi Diri dan Keterikatan Karyawan terhadap Kinerja Karyawan (Studi Pada Patra Semarang Hotel \& Convention)" Diponegoro Journal of Management 6 (3): 1-11.

Ardiani, Firda, and Olievia Prabandini Mulyana. (2018). "Hubungan Antara Efikasi Diri dengan Kepuasan Kerja pada Karyawan Bank Pembiayaan Rakyat Syariah.” Jurnal Penelitian Psikologi 5 (2): 1-5.

Ary, Iwan Restu, and Anak Agung Ayu Sriathi. (2019). "Pengaruh Self Efficacy dan Locus of Control terhadap Kinerja Karyawan (Studi Pada Ramayana Mal Bali).” E-Jurnal Manajemen Universitas Udayana 8 (1): 6990-7013. https://doi.org/10.24843/ejmunud.2019.v08.i01.p02.

Bagaskara, Bagus Ikhsan, and Edy Rahardja. (2018). “Analisis Pengaruhmotivasi Kerja, Disiplin Kerja dan Kepuasan Kerja terhadap Kinerja Karyawan (Studi Pada PT. Cen Kurir Indonesia, Jakarta)." Diponegoro Journal of Management 7 (2): 1-11.

Candra, Adella Novita. (2017). "Motivasi terhadap Kinerja Tim Bisnis dengan Variabel Pemediasi Self Efficacy.” Jurnal Manajemen Dan Start-up Bisnis 2 (2): 151-161.

Candra, Yeki. (2019). "Pengaruh Self-Efficacy, Locus Of Control terhadap Kepuasan Kerja Karyawan dengan Budaya Organisasi Sebagai Variabel Pemoderasi Puskesmas Air Haji Kabupaten Pesisir Selatan.” Jurnal Ekonomi Dan Manajemen Sistem Informasi 1 (2): 94-105.

Changgriawan, Garry Surya. (2017). "Pengaruh Kepuasan Kerja dan Motivasi Kerja terhadap Kinerja Karyawan di One Way Production.” Jurnal Agora 5 (3): 1-7.

Cherian, Jacob, and Jolly Jacob. (2013). "Impact of Self Efficacy on Motivation and Performance of Employees" International Journal of Business and Management 8 (14): 80-88. https://doi.org/10.5539/ijbm.v8n14p80.

Desiana, Nofi Eka. (2018). "Pengaruh Efikasi Diri terhadap Kinerja Karyawan Melalui Inovasi sebagai Variabel Intervening (Studi Pada Divisi Sekretariat Dan Humas Pdam Surya Sembada Kota Surabaya).” Jurnal Ilmu Manajemen (JIM) 7 (2): 382-392.

Dewi, P.E.P., and I G. A. M. Dewi. (2015). "Pengaruh Self-Efficacy dan Motivasi Kerja pada Kepuasan Kerja Karyawan Happy Bali Tour \& Travel Denpasar.” Jurnal Manajemen, Strategi Bisnis Dan Kewirausahaan 9 (1): 15-25.

Harjono, Gerald Joseph, Bode Lumanauw, and Kana Kaisar. (2015). "Pengaruh Kepemimpinan Transformasional dan Self Efficacy Terhadap Kinerja Pegawai Pt. Air Manado." Jurnal EMBA: Jurnal Riset Ekonomi, Manajemen, Bisnis Dan Akuntansi 3 (3): 1040-1049.

Kartika, Jeffrey Agung, Kevin Cahyadi T.K, and Deborah C Widjaja. (2018). "Pengaruh Self Efficacy Terhadap Kepuasan Kerja dan Kinerja Karyawan Di Hotel Maxone Dharmahusada Surabaya." Jurnal Hospitality dan Manajemen Jasa 6 (2): 135-149.

Kilapong, Samuel N. (2013). "Kepemimpinan Transformasional, Self Efficacy, Self-Esteem 
Fauzan Ali, Dewie Tri Wijayati Wardoyo. Pengaruh Self efficacy terhadap Kinerja Karyawan dengan Kepuasan Kerja sebagai Variabel Intervening (Studi PT. Ultrajaya Milk Industry, Tbk Surabaya Bagian Marketing)

Pengaruhnya terhadap Kepuasan Kerja Karyawan PT. Tropica Cocoprima Manado" Jurnal EMBA 1 (4): 141-150.

Mangkunegara, A.P. (2009). Sumber Daya Manusia dan Perusahaan. Edisi 2. Cetakan Kelima. Bandung: PT. Remaja Rodakarya.

Mathis, Robert L., and John H. Jackson. (2011). Human Reserch Management. Edisi 10. Jakarta: Salemba Empat.

Mukrodi. (2018). "Pengaruh Efikasi Diri terhadap Kinerja Karyawan PT. Express Kencana Lestari (Express Group) Depok.” Kreatif 6 (1): 88-94.

Narendra, Gilang. (2017). "Pengaruh Efikasi Diri Terhadap Kepuasan Kerja dengan Motivasi Sebagai Variabel Intervening pada PDAM Surya Sembada Kota Surabaya." Jurnal Ilmu Manajemen (JIM) 5 (3).

Noviawati, Dian Rizki. (2016). "Pengaruh Self Efficacy Terhadap Kinerja Karyawan Dengan Motivasi Sebagai Variabel Intervening." Jurnal Ilmu Manajemen 4 (3): 1-12.

Nugraha, Naufaldy Pratama. (2019). "Pengaruh Kompetensi Pola Pikir Bakat dan Efikasi Diri Tterhadap Kinerja Karyawan Melalui Kepuasan Kerja.” Jurnal Ekonomi dan Bisnis 12 (13): 115.

Nurul, C. R., and E Rahardja. (2019). "Pengaruh Kualitas Kehidupan Kerja, Motivasi Kerja, dan Kepuasan Kerja terhadap Kinerja Karyawan (Studi Pada PT. Djarum Kudus)." Diponegoro Journal of Management 8 (3): 128-137. http://ejournal-s1.undip.ac.id/index.php/djom ISSN (Online): 2337-3792.

Prasetya, Veronika, Dwi Handayani, and Theresia Purbandari. (2013). "Peran Kepuasan Kerja, Self Efficacy terhadap Kinrerja Individul.” Jurnal Riset Manajemen dan Akuntansi 1 (1): 59-69.

Priyantono, Ponco. (2017). "Pengaruh Self-Leadership, Self-Efficacy dan Motivasi Terhadap Kinerja." Jurnal Manajemen 6 (2): 131-151.

Rahman, Muhammad Fajar Wahyudi, and Kistyanto, Anang. (2019). "Hubungan Antara Iklim Psikologis terhadap Kinerja Karyawan Melalui Kepuasan Kerja” 12 (2): 410-429.

Robbins, Stephen P., and Timothy A. Judge. (2016). Perilaku Organisasi. Edisi 16. Jakarta: Salemba Empat.

Salanka, and Dotulong. (2015). "Pengaruh Self Efficacy, Self Esteem dan Lingkungan Kerja terhadap Kepuasan Kerja Karyawan Pada PT. PLN (Persero)” 3 (3): 562-572.

Santoso, Agus, and I.G.A Manuati Dewi. (2019). "Pengaruh Efikasi Diri, Motivasi Kerja, Lingkungan Kerja terhadap Kepuasan Kerja Karyawan PT. Sukanda Djaya Denpasar.” E-Jurnal Manajemen Universitas Udayana 8 (11): 1-7. https://doi.org/10.24843/ejmunud.2019.v08.i11.p06.

Sihombing, Eko Parlindungan, Greis M Sendow, and Yantje Uhing. (2018). "Pengaruh Karakteristik Individu Karakteristik Pekerjaan dan Self Efficacy Terhadap Kinerja Karyawan Pada PT. PLN (Persero) Rayon Manado Selatan" Jurnal EMBA 6 (4): 2858-2867.

Sunanda, Wahidya Difta. (2019). "Pengaruh Kepemimpinan Islami dan Religiusitas terhadap Kinerja Karyawan melalui Kepuasan Kerja Karyawan Sebagai Variabel Intervening (Studi Kasus Pada Waroeng Spesial Sambal).” Jurnal Ilmu Manajemen, UNY 17(1): 20-36. 
Tojjari, Farshad, Mohammad Reza Esmaeili, and Reza Bavandpour. (2013). "The Effect of SelfEfficacy on Job Satisfaction of Sport Referees" Pelagia Research Library, 3 (2): 219-225.

Tri Wijayati, Dewie, Fazlurrahman Hujjatullah, Hadi Hafid Kholidi, Rahman Zainur, and Kautsar Achmad. (2020). "Coaching As Determinant of Job Performance: Co-Working Support As Mediating Variable." KnE Social Sciences 2020 (2015): 240-250. https://doi.org/10.18502/kss.v4i7.6855.

Yasa, Putu Ngurah Suyatna, and Yasa Ketut Suandra. (2017). "The Influence of Job Satisfaction on Organizational Citizenship Behavior through the Mediation of Organizational Commitment (A Case Study in the Westin Resort Nusa Dua, Bali)." Journal of Law, Policy and Globalization 57: 64-74. 